\title{
DC ARC FURNACES - PAST, PRESENT, AND FUTURE
}

\author{
Rodney T. Jones \\ Mintek; 200 Malibongwe Drive, Private Bag X3015, Randburg, 2125, South Africa
}

Keywords: Pyrometallurgy, DC arc furnace, electric arc, smelting

\begin{abstract}
DC arc furnaces were first used industrially for the reductive smelting of chromite fines to produce ferrochromium thirty years ago. Since then, they have been used for a variety of applications, including the smelting of ilmenite to produce titania slag and pig iron, the recovery of cobalt from non-ferrous smelter slags, and the smelting of nickel laterite ores to produce ferronickel. The power of these furnaces has increased from $12 \mathrm{MW}$ to $72 \mathrm{MW}$ for ferrochromium, and to $80 \mathrm{MW}$ for ferronickel. The largest of these furnaces requires two electrodes to carry sufficient current to generate this much power. A review is presented of various DC arc furnaces in use, along with a discussion of the likely ways in which furnace power might be increased further in the future.
\end{abstract}

\section{Introduction and History}

\section{Early Description of an Arc by Humphry Davy}

The earliest known written description of a man-made electric arc emanated from Humphry Davy's work in the early 1800s. His early experiments in 1800, only a few months after Volta's introduction of the electric battery, involved the production of sparks during the making and breaking of an electric circuit.

"I have found that this substance [well burned charcoal] possesses the same properties as metallic bodies in producing the shock and spark when made a medium of communication between the ends of the galvanic pile of Signor Volta. The spark is most vivid when the charcoal is hot." [1]

In his 1812 book, Elements of Chemical Philosophy [2], Sir Humphry Davy provides the first description and diagram (reproduced in Figure 1) of the long horizontal arch of flame that gives the arc its name.
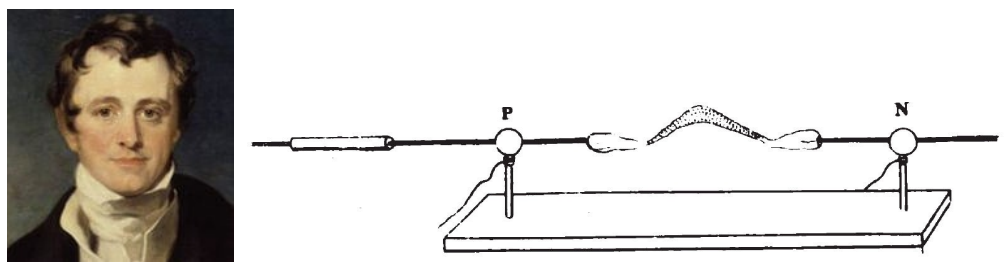

Figure 1. Sir Humphry Davy and a horizontal 'arch' electrical discharge, as shown in Davy's 'Elements of Chemical Philosophy' 
"When pieces of charcoal about an inch long and one sixth of an inch in diameter, were brought near each other (within the thirtieth or fortieth part of an inch), a bright spark was produced, and more than half the volume of the charcoal became ignited to whiteness, and by withdrawing the points from each other a constant discharge took place through the heated air, in a space equal at least to four inches, producing a most brilliant ascending arch of light, broad, and conical in form in the middle. When any substance was introduced into this arch, it instantly became ignited; platina melted as readily in it as wax in the flame of a common candle; quartz, the sapphire, magnesia, lime, all entered into fusion; fragments of diamond, and points of charcoal and plumbago, rapidly disappeared, and seemed to evaporate in it, even when the connection was made in a receiver exhausted by the air pump; but there was no evidence of their having previously undergone fusion.” [2]

\section{Arc Furnace by Sir William Siemens}

The idea behind the (direct current) DC arc furnace has been around for a very long time. Its use for the bulk melting of metals dates back at least to 1878, when Sir William Siemens used a DC arc furnace with a vertical graphite cathode, with the arc transferred to the melt in contact with a water-cooled bottom anode (shown in Figure 2) [3].
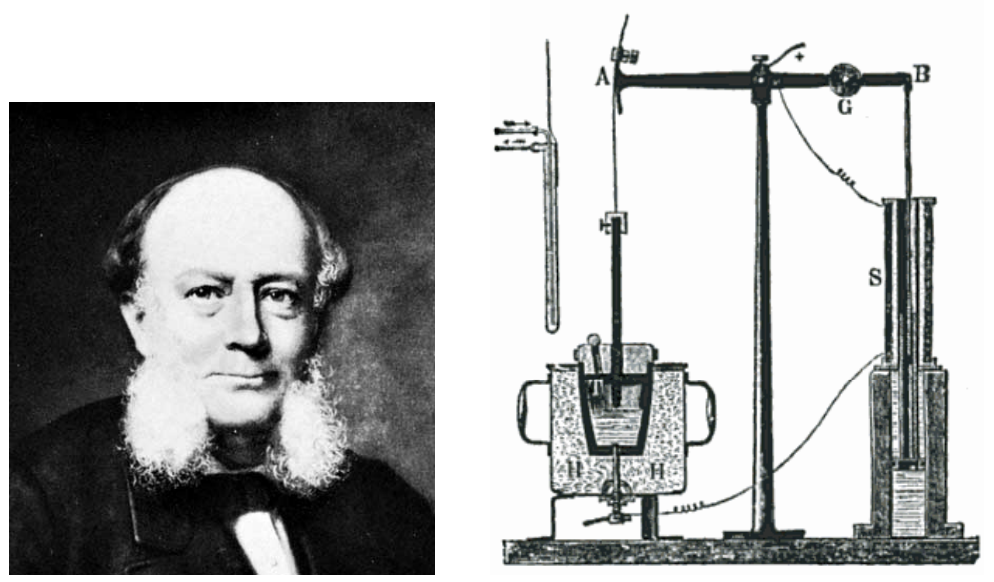

Figure 2. Sir William Siemens and the DC furnace he patented in 1878

About two decades after this, the first AC (alternating current) electric arc furnace, invented by Paul Héroult, was patented and first operated in La Praz, France, in 1900. The first AC furnace in the USA was installed in 1906 in Philadelphia. Electric furnace technology became almost entirely AC based thereafter, because of the use of AC for efficient power transmission from large central power stations (following developments by Nikola Tesla and George Westinghouse in 1887 and 1888) and the use of local step-down transformers to supply the high currents required in the furnaces. 
Significant commercialisation of DC furnace technology occurred in the 1990s, when there was a huge demand for DC arc furnaces for steel scrap melting, following the development of highpower solid-state rectifiers. Around that time, about $80 \mathrm{DC}$ arc furnaces were built in the northern hemisphere.

\section{Features of DC Arc Furnaces}

A DC arc furnace typically comprises a refractory-lined cylindrical steel shell, with a central graphite (cathode) electrode vertically positioned through an opening in the centre of the roof. The anode connection in the hearth of the furnace is in direct contact with the layer of molten metal that is covered by a layer of molten slag. The energy is supplied by means of an open plasma arc that is generated between the bottom tip of the cathode and the upper surface of the molten slag. At least a central portion of the slag surface is open (uncovered by feed material). Because the furnace is electrically powered, very high temperatures $\left(>1500^{\circ} \mathrm{C}\right)$ can be attained. The open bath allows fine feed materials to be fed into the furnace, without risk of blocking the gas emanating from the chemical reactions. (By contrast, in a blast furnace, or in a submergedarc furnace, coarse feed materials are required in order to provide a porous bed that allows the reaction gases to percolate away and escape from the reaction zone.)

Finer ores and a requirement for very high temperature lead one to the choice of an open-arc furnace (either AC or DC). It should be noted that fine ores allow the use of a fluidized-bed reactor for pre-heating or pre-reduction, and this can provide significant energy savings when used in conjunction with a DC arc furnace.

In the case of open-arc furnaces, DC furnaces have a number of advantages over AC furnaces. One particular advantage in a circular furnace is that there is no arc repulsion in the case of the single DC arc, compared to the AC case where the arcs repel one another, flaring towards the walls, leading to hot spots on the areas of the side-walls in closest proximity to the electrodes. DC furnaces also experience lower electrode consumption. In large DC furnaces, a higher current can be carried per electrode (or smaller electrodes can be used for the same current), because of the AC 'skin effect' where current is concentrated in the outer periphery of the electrodes.

\section{Some Past and Current Applications of DC Arc Furnaces}

\section{Early Developments in the Application of DC Arc Furnaces to Chromite Smelting}

South Africa is very fortunate in having large reserves of chromite. Unfortunately a lot of the 'Transvaal chromites' are highly friable, resulting in large stockpiles of fine ore materials. This posed a particular challenge to Mintek to provide a solution to this problem. Peter Jochens of Mintek identified 'plasma furnaces' as a possible solution to the 'chromite fines' problem. Mintek and Middelburg Steel \& Alloys (now part of Samancor Chrome) conducted smelting trials on Tetronics' pilot transferred-arc plasma furnaces in the UK in 1979/80. These trials showed successful metallurgy, but this type of furnace was seen as difficult to scale up to the very large furnaces that were required for the ferro-alloys industry.

Around about the same time, also in the 1970s, ASEA in Sweden developed high-power thyristor rectifiers. Sven-Einar Stenkvist investigated the conversion of AC open arc furnaces to DC, principally for steelmaking. He implemented the idea of using a graphite cathode electrode 
arcing onto a slag/metal bath as the anode, and devised an electrically conductive hearth and a hollow graphite electrode for finely sized iron ore smelting, where the feed material is fed through the electrode and through the heart of the plasma arc. This is shown in Figure 3.

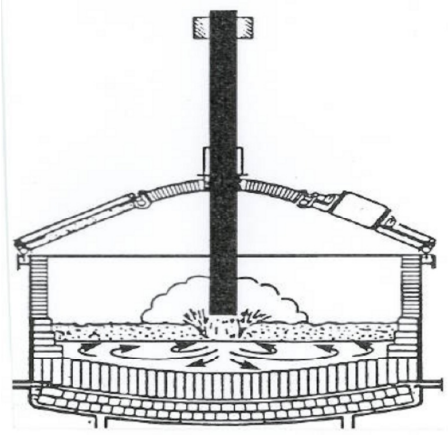

Figure 3. ASEA's DC arc furnace

Nic Barcza of Mintek recognised the synergy between the metallurgy that was proven during the Tetronics testwork, and the scale-up potential of ASEA's DC arc furnace. This is where the application of pre-baked graphite electrodes in a DC arc furnace came about. Mintek built a 1.2 MW DC arc furnace in 1983 to support this development. Since then, that concept has been applied in a number of areas.

The first industrial application of a DC arc furnace for smelting came about when Middelburg Steel \& Alloys converted an existing AC furnace at Palmiet Ferrochrome (now Mogale Alloys) in Krugersdorp to a 12 MW DC arc furnace of ASEA design in 1984.

\section{Chromite Smelting}

Mintek [4] began investigating alternative smelting methods for ferro-alloy production in the mid to late 1970s. The growing ferro-alloy industry in South Africa faced the problem of how to deal with the significant quantity of fine material $(<6 \mathrm{~mm})$ that was generated from the friable local chromite ores. In 1976, studies commenced on the possible use of plasma smelting (DC transferred-arc technology), motivated by its potential ability to utilise fine feed materials directly, without costly agglomeration. A further advantage was that the metallurgical and electrical parameters of the smelting process are independent, unlike in a conventional submerged-arc furnace [5].

In 1979, Middelburg Steel \& Alloys, now part of Samancor Chrome, asked Mintek to take part in tests on plasma smelting at Tetronics in the United Kingdom. After that, Mintek committed itself to the investigation of plasma technology, and to the demonstration to industry of its benefits, particularly the ability to smelt fine materials. Equipment for this purpose was installed in Mintek's pilot bays, and was based initially on a power supply of $100 \mathrm{kVA}$, and later on another of 3.2 MVA. The first such ferrochromium was produced in a bench-scale DC arc furnace in 1979. The installation of the large experimental furnaces in Mintek's pyrometallurgy pilot bay, Bay 1, demanded an extension of the original building, and, in June 1982, a formal 
opening ceremony marked not only the completion of the building operations, but also the inauguration of the larger 3.2 MVA furnace. The $1 \mathrm{t} / \mathrm{h}$ DC arc furnace pilot plant was commissioned in 1984.

As a result of successful initial testwork, Mintek and Middelburg Steel \& Alloys undertook a longer-term R\&D programme to develop the technology commercially. Based on testwork at 0.3 - 0.5 MW in furnaces $1-2 \mathrm{~m}$ in diameter, the initial industrial-scale 16 MVA (12 MW) transferred-arc furnace was installed at the Krugersdorp (Palmiet Ferrochrome) plant of Middelburg Steel \& Alloys at the end of 1983, then upgraded (around 1987) to 40 MVA ( $\sim 33 \mathrm{MW}$ ) in 1988. An additional $10 \mathrm{MW}$ furnace was later built on the same site (for Mogale Alloys).

Chromite is smelted together with some form of carbon to produce ferrochromium, along with some slag and some CO gas. The DC arc furnace operates with an open-arc, open-bath configuration, so there is no heaped burden through which the reaction gases would need to escape. There is simply a molten bath onto which the fine material is dropped, and it almost immediately assimilates into the molten bath, melting and dissolving into the slag phase where the reactions take place. This furnace does not require coke because there is no burden above the bath so it doesn't require the porosity that would otherwise be needed. This is a very significant advantage, in that it allows the use of inexpensive reductants, thereby avoiding the high cost and relative scarcity of coke.

The power supplied to the furnace is largely independent of the slag composition, because there is an open electric arc that allows one to adjust the amount of power going into the furnace independently of the electrical resistivity of the slag. This provides extra flexibility and an extra degree of freedom of a change in slag composition unconstrained by electrical properties, so that the chemical activities of the important metals can be changed to achieve higher chromium recovery. A typical increase in chromium recovery could be from about $85 \%$ in an AC furnace to about $95 \%$ in a DC arc furnace - a very significant increase. In addition, the DC arc furnace has lower electrode consumption. The DC-arc process allows the use of unagglomerated chromite fines and cheaper, non-coking coal. This furnace technology is regarded as one of the lowest-cost options for the production of ferrochromium.

Based on the successful operation of the DC arc furnace for chromite smelting at Krugersdorp, Middelburg Ferrochrome (now part of Samancor Chrome) built a 44 MW (62 MVA) DC arc furnace, the largest of its type, in Middelburg in 1997. This was followed, in 2009, by an additional $60 \mathrm{MW}$ furnace in Middelburg, currently the largest DC arc furnace in South Africa [6]. The $44 \mathrm{MW}$ furnace was subsequently upgraded to $60 \mathrm{MW}$.

\section{$\underline{\text { Ilmenite Smelting }}$}

Ilmenite is smelted to produce titania slag (mostly for pigment production) and pig iron. Ilmenite from beach sands in South Africa is of too low a grade to be used directly for the production of pigment or synthetic rutile. Instead, it is smelted to produce a titania slag suitable for the production of $\mathrm{TiO}_{2}$ pigments. The principal reaction involved is shown simplistically as:

$$
\mathrm{FeO} \cdot \mathrm{TiO}_{2}+\mathrm{C}=\mathrm{TiO}_{2}+\mathrm{Fe}+\mathrm{CO}
$$


The high electrical conductivity of titania slags and the required accurate control of the slag composition effectively rule out the use of conventional submerged-arc technology for the smelting of ilmenite. Richards Bay Minerals (RBM) uses process technology originally developed by Quebec Iron \& Titanium (QIT Fer et Titane) of Sorel, Canada, employing rectangular six-in-line graphite-electrode furnaces in open-bath mode with AC open-arc operation.

An alternative to this process, based on single hollow-electrode DC-arc furnace technology, was developed by Mintek and Anglo American Corporation for the Namakwa Sands project. The problem that needed to be solved was to find alternative equipment in which to produce a very conductive slag. Because the slag is so conductive, it is not feasible to obtain sufficient resistive heating in the molten slag, and it is, therefore, necessary to use an open arc. (This is a very different reason for using a DC arc furnace from that requiring it for smelting chromite fines.)

Phase one of the testwork, in 1990, involved four $15 \mathrm{~kg}$ batch tests at $30 \mathrm{~kW}$, and showed that the process was feasible, and that a freeze lining was required. Phase two, in 1991, involved smelting two metric tons of ilmenite, with continuous feeding at $50 \mathrm{~kg} / \mathrm{h}$, at a power level of $100 \mathrm{~kW}$. This produced an on-specification slag, and a metal that was high in Ti. Phase three, also in 1991, saw the smelting of 35 tons of ilmenite, fed continuously at $300 \mathrm{~kg} / \mathrm{h}$, at power levels of $500 \mathrm{~kW}$ (to $1 \mathrm{MW}$ ), with on-grade slag and metal produced. Phase four, in 1995, processed 200 metric tons of ilmenite at $1 \mathrm{t} / \mathrm{h}$ and $1.5 \mathrm{MW}$, and primarily involved the development of the furnace start-up procedure, process control, and operator training.

Following the $0.5 \mathrm{MW}$ pilot-plant testwork in a $1.8 \mathrm{~m}$ diameter furnace, the first $25 \mathrm{MW}$ DC arc furnace at Namakwa Sands was constructed in 1994, followed by a 35 MW DC furnace in 1998. The first (25 MW) furnace began production of ilmenite slag and pig iron in June 1995, and the second furnace (35 MW) was brought on line in February 1999 [7].

Based on that success, without any further testwork being required at Mintek, two further 36 MW DC furnaces for ilmenite smelting were built for Ticor SA, near Empangeni, and were commissioned in 2003.

A further 30 MW furnace was built by Bateman and commissioned for CYMG in China in 2009.

\section{Nickel laterite smelting}

Laterites and other oxidized nickel ores constitute a very important part of worldwide nickel reserves. In the conventional production of ferronickel from these ores, much fine material is produced which cannot readily be accommodated directly in existing three-electrode or six-inline AC furnaces. DC arc furnace technology allows ore particles less than $1 \mathrm{~mm}$ in size to be treated directly, thereby improving the overall recovery of nickel without the need for expensive agglomeration techniques. Because of the high moisture content of laterites, the ores should be dried and calcined before smelting. A further saving in energy consumption can be achieved by pre-reducing the ores.

Mintek has been working on the production of unrefined ferronickel from nickel-containing laterite in DC arc furnaces since 1993. In this process, lateritic material is fed, together with a carbonaceous reducing agent, to the central region of the molten bath of a cylindrical DC arc furnace. A wide compositional range of nickel laterites can be smelted in this way. The flexible 
operation of a DC arc furnace (especially its lower dependence on electrical properties of the slag, because of open-arc operation, in addition to the ability to run at an optimum slag temperature, due to the open-bath mode of operation) allowed for the successful treatment of ores with a $\mathrm{SiO}_{2} / \mathrm{MgO}$ ratio between 1.2 and 3.0, as well as ores containing up to 30 per cent by mass of iron (which tends to cause slag foaming in a conventional immersed-electrode furnace). A frozen lining can be maintained between the molten bath and the refractory lining, in order to minimize refractory wear (especially at high $\mathrm{SiO}_{2}$ contents). The smelting of nickel laterite to produce ferronickel was piloted at Mintek [8] from 1993 to 2006, using a wide variety of feed materials.

The first commercial application of the DC FeNi process was a 12 MW DC arc furnace in Orsk in the Southern Urals, Russia, commissioned in September 2011 [9].

\section{Present}

\section{Kazchrome}

Kazchrome (a ferrochromium producer in Kazakhstan) contracted with Mintek in 2007 to undertake smelting testwork. Based on this, and on other design inputs provided by Mintek in 2009, SMS Siemag has built four 72 MW DC arc furnaces in Aktobe, Kazakhstan, and commissioning was scheduled to begin in 2013. Each of these furnaces features an automated online electrode changer for the $75 \mathrm{~cm}$ graphite electrodes, and a suspended roof.

\section{$\underline{\text { Koniambo Nickel }}$}

The largest application of DC arc furnace smelting technology is the Koniambo Nickel project in New Caledonia - a greenfield joint venture partnership between Société Minière du Sud Pacifique (SMSP) and Glencore Xstrata. The process is based on milled ore, fluidized beds, and two twin-electrode $80 \mathrm{MW}$ DC arc furnaces, with cyclone pre-heaters. Each $71 \mathrm{~cm}$ graphite electrode has a separate $40 \mathrm{MW}$ power supply (transformer and rectifier). The smelting testwork for this project was carried out at Mintek in the late 1990s. The Koniambo ferronickel smelter, which will employ about 800 people, aims to produce $60 \mathrm{kt} / \mathrm{a}$ of $\mathrm{Ni}$ in FeNi from one of the world's largest and highest-grade nickel laterite deposits. The smelter commissioning began in 2012, and the first metal from the furnace was produced in April 2013 [10].

\section{List of DC arc furnaces used for smelting applications}

Table I. DC furnace installations

\begin{tabular}{|l|c|c|}
\hline \multicolumn{1}{|c|}{ Process } & Year & Furnaces \\
\hline Steel & & > 80 DC furnaces, up to 175 MW \\
\hline FeCr & 1985 & 10MW, 30MW, 60MW, 60MW, (4 x 72MW) \\
\hline TiO2 & 1994 & 25MW, 30MW, 35MW, 36MW, 36MW \\
\hline Co & 2001 & $40 \mathrm{MW}$ \\
\hline Stainless steel dust & 2004 & 32MW \\
\hline Battery recycling & 2008 & 2.5MW \\
\hline FeNi & 2011 & 12MW, (2 x 80MW) \\
\hline
\end{tabular}




\section{Future}

Very large DC arc furnaces are currently in use in the steel industry. For example, in 2007, Tokyo Steel ordered the world's largest electric arc furnace (EAF) from Danieli. This furnace has a $420 \mathrm{t}$ liquid steel capacity. It is a twin-cathode DC arc furnace, with four bottom electrodes. The power supply includes $8 \times 32$ MVA transformers, making up a total of 256 MVA. The operating power is $175 \mathrm{MW}$. Danieli claims that it overcomes the limits of power input in the EAF, and reduces graphite electrode consumption, as compared with AC and single-cathode DC furnaces, and disturbances on the power supply network are minimized due to the double-arc effect.

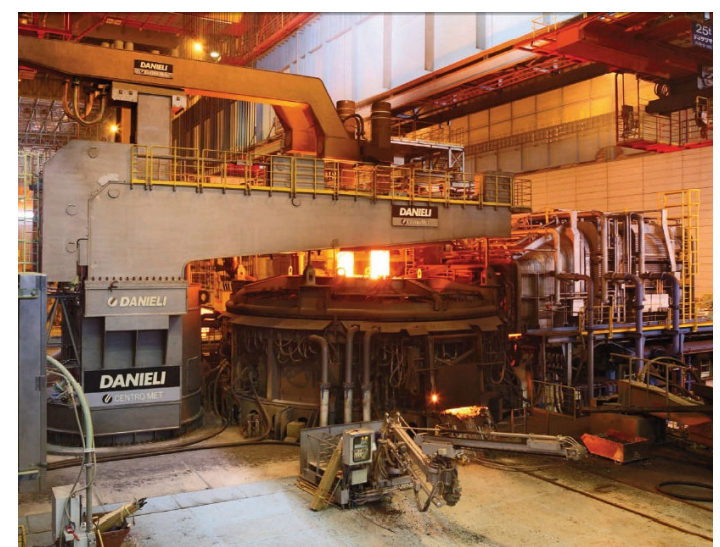

Figure 4. Tokyo Steel's $175 \mathrm{MW}$ twin-cathode DC arc furnace

The largest DC furnace used in the steel industry (175 MW) is substantially larger than the largest of the DC smelting furnaces (currently $80 \mathrm{MW}$ ). Perhaps the steel industry will lead the way for future expansions in capacity elsewhere.

\section{Speculative Design of Very Large Furnaces}

The economy of scale creates an inexorable push towards larger furnaces in the ferro-alloy industry. However, the AC type of submerged-arc furnace as is commonly used at present has certain fundamental limits, and so conversions to other forms of furnace are likely. Once this 'AC barrier' has been overcome, scale up will probably involve larger electrodes and more electrodes. This could be applied to either DC open-arc furnaces or submerged-arc furnaces. The potential for the scaling up of Söderberg electrodes will only be known once this AC barrier has been overcome, and larger furnaces have been tried in practice.

Barker and Barcza et al. [11,12] pointed out how DC power can overcome some of the constraints imposed on AC submerged-arc furnaces used for ferro-alloy production, namely the current-carrying capacity of the electrodes, and the interaction effect in the control of the electrodes. 
The limiting current $I$ (in $\mathrm{kA}$ ) carried by a Söderberg electrode of diameter $d$ (in $\mathrm{m}$ ) is represented by equation (2).

$$
I=55 d^{1.5}
$$

Graphite electrodes can carry almost double the current of Söderberg electrodes of the same diameter.

A larger Söderberg electrode tends to give more trouble than a smaller one, for two principal reasons: the strength-to-weight ratio deteriorates as the electrode is scaled up, and the skin effect (the tendency of alternating current to keep to the outside of a conductor) distorts the distribution of the current flowing in the electrode. The skin effect applies only to AC, not DC. At $50 \mathrm{~Hz}$, the 'skin depth' is around $35 \mathrm{~cm}$ for Söderberg electrodes, and about $15 \mathrm{~cm}$ for graphite electrodes. Large electrodes are expected to behave better in a DC furnace.

Probably the greatest challenge for the operator of a ferro-alloy furnace with Söderberg electrodes is to balance the baking-slipping rates of the electrodes, as required to maintain electrode lengths. Pre-baked and graphite electrodes do not have this limitation, because they can be slipped as much or as little as required.

Because the power factor typically decreases as the size of an AC furnace increases, the interaction effect is probably one of the main constraints on building larger AC furnaces. Electro-magnetic inductance creates reactance only with alternating current. Therefore, with DC power, there are no constraints from the reactance side. In particular, with a multi-electrode DC furnace, each electrode behaves individually - i.e., there is no interaction effect.

Because the voltages on adjacent electrodes in a multi-electrode DC furnace are similar, and the electrodes do not interact with each other operationally, they can in theory be mounted closer together, should the need arise. It is also worth noting that the flares in a multi-cathode DC furnace will be directed inwards, unlike the outwardly directed flares in an AC furnace.

As the nature of power generation changes in response to environmental challenges, and more renewable energy is used, the ability to swing the furnace load is likely to bring significant economic advantages, and so might become common practice, in spite of the nuisance factors that this will incur with the operation of the plant. It would seem that larger furnaces might also be better than present furnaces at handling power dips and outages for a longer time, and DC furnaces could offer significant advantages when it comes to easy and fast swinging of the load.

Barker [11] proposed a speculative 6-electrode furnace design with the electrodes arranged in a circle. Each electrode would be fed by its own power supply module, using DC power. Barker suggests that, in the future, one could perhaps contemplate Söderberg electrodes with a diameter of $3.0 \mathrm{~m}$ (only about $50 \%$ larger than the largest electrodes that are presently in use), able to carry a current in excess of $250 \mathrm{kA}$. A large 6-electrode DC arc furnace could then have a total power of over $200 \mathrm{MW}$.

The questions remain as to how much current can be removed from the bottom of the furnace, and how long such connections can be kept functioning. 


\section{Conclusions}

DC arc furnaces have some wonderful features that have been proven in industrial practice over the past thirty years. They are good at accommodating finely sized feed materials (because of the open bath). They do not require coke or char (no burden porosity required). DC arc furnaces can treat feed materials with a wide range of composition (because of the extra degree of freedom coming from power being supplied by an open arc); this allows choice of chemistry for metallurgical benefit. These furnaces are geometrically simple and elegant, thereby reducing uneven wear on side-walls, and leading to lower costs.

However, there are some drawbacks. Thermal efficiency is decreased by the hot off-gas leaving the furnace (unless some of this energy is recovered). The absence of a burden does not allow for the capture of volatile species.

DC arc furnaces are not a panacea for all metallurgical problems, but are very well suited to a number of reductive smelting processes where they have been applied successfully in a number of industrial contexts, and many further applications are expected.

\section{Acknowledgements}

This paper is published by permission of Mintek. Support from the National Research Foundation (NRF) of South Africa is gratefully acknowledged.

\section{References}

1. Humphry Davy, "VII. Additional Experiments on Galvanic Electricity", Journal of Natural Philosophy, Chemistry, and the Arts (Nicholson's Journal), London, Vol.IV, October 1800, 326328.

2. Sir Humphry Davy, Elements of Chemical Philosophy: Part 1 Vol.1 (London: J. Johnson and Co., St Paul's Church Yard, 1812), p.85 and Plate III, Fig.18.

https://archive.org/details/elementschemica00davygoog

3. English patents, No. 4208 of 1878 and No. 2110 of 1879.

4. R.T. Jones and T.R. Curr, "Pyrometallurgy at Mintek", Southern African Pyrometallurgy 2006, Edited by R.T. Jones, SAIMM, Johannesburg, 5-8 March 2006, pp.127-150.

http://www.mintek.co.za/Pyromet/Files/2006JonesMintek.pdf

5. R.T. Jones, T.R. Curr, and N.A. Barcza, "Developments in Plasma Furnace Technology", High-Intensity Pyrometallurgy, The Institution of Mining and Metallurgy, 4 February 1993, London.

http://www.mintek.co.za/Pyromet/Files/PlasmaDev.pdf

6. D. Sager, D. Grant, R. Stadler, and T. Schreiter, "Low cost ferroalloy extraction in DC-arc furnace at Middelburg Ferrochrome”, (Infacon 12, Helsinki, 6-9 June 2010), SAIMM Journal, Vol.110, No.12, December 2010, pp.717-724.

http://www.pyrometallurgy.co.za/InfaconXII/803-Sager.pdf

http://www.saimm.co.za/Journal/v110n12p717.pdf 
7. M. Gous, "An overview of the Namakwa Sands ilmenite smelting operations", Southern African Pyrometallurgy 2006, Edited by R.T. Jones, South African Institute of Mining and Metallurgy, Johannesburg, 5-8 March 2006, pp.189-201.

http://www.pyrometallurgy.co.za/Pyro2006/Papers/189_Namakwa.pdf

8. H. Lagendijk and R.T. Jones, "Production of ferronickel from nickel laterites in a DC-arc furnace”, Nickel-Cobalt 97, 36th Annual Conference of Metallurgists, Sudbury, Canada, 17-20 August 1997, pp. 151-162.

http://www.mintek.co.za/Pyromet/Laterite/Laterite.htm

9. C.P. Naude and M.D. Shapiro, "Implementation of the first commercial scale DC smelter for ferronickel production from low grade laterite ores-technology building blocks and lessons learned”, Journal of the Southern African Institute of Mining and Metallurgy, vol.110, no.12, December 2010. pp.725-732.

http://www.saimm.co.za/Journal/v110n12p725.pdf

10. Mining Journal, “Xstrata's Koniambo produces first nickel”, Mining Journal, 11 April 2013. http://www.mining-journal.com/exploration--and--development/xstratas-koniambo-producesfirst-nickel

11. I.J. Barker, "Some considerations on future developments in ferro-alloy furnaces", Southern African Pyrometallurgy 2011, Edited by R.T. Jones \& P. den Hoed, SAIMM, Johannesburg, 6-9 March 2011, pp.1-13.

http://www.pyrometallurgy.co.za/Pyro2011/Papers/001-Barker.pdf

12. N.A. Barcza, I.J. Barker, M.S. Rennie, and P.J. Brereton-Stiles, "The application and scaleup of AC and DC smelting furnaces for ferro-alloys", 60th Electric Furnace Conference Proceedings, Vol. 60, Warrendale, PA: Iron \& Steel Society, 2002. pp. 425-437.

http://www.mintek.co.za/Pyromet/Files/2002Barcza.pdf 


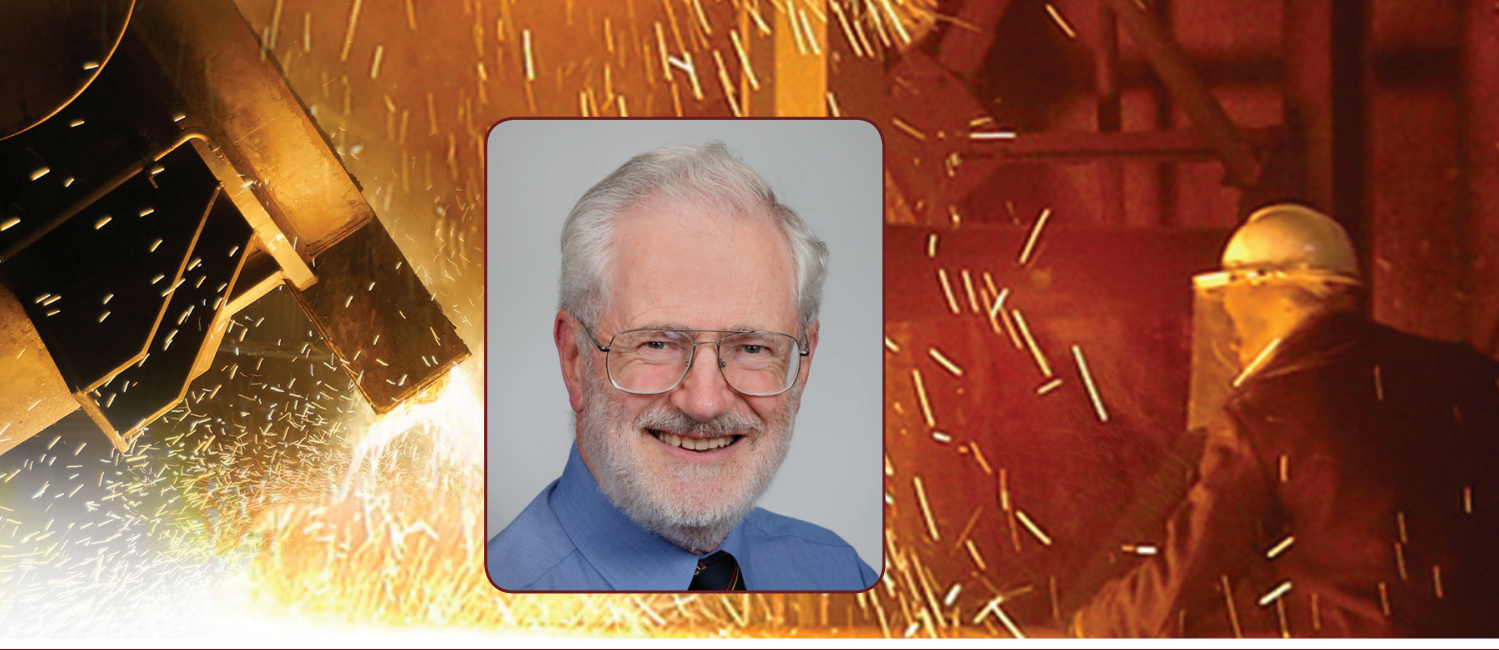

\section{GELEBRATING THE

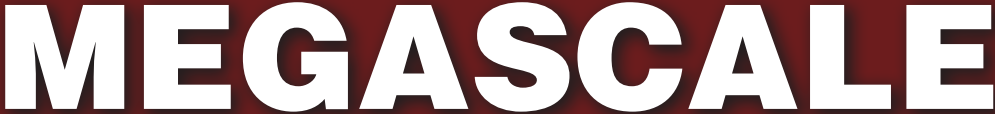

Proceedings of the Extraction and Processing

Division Symposium on Pyrometallurgy in Honor of David G.C. Robertson

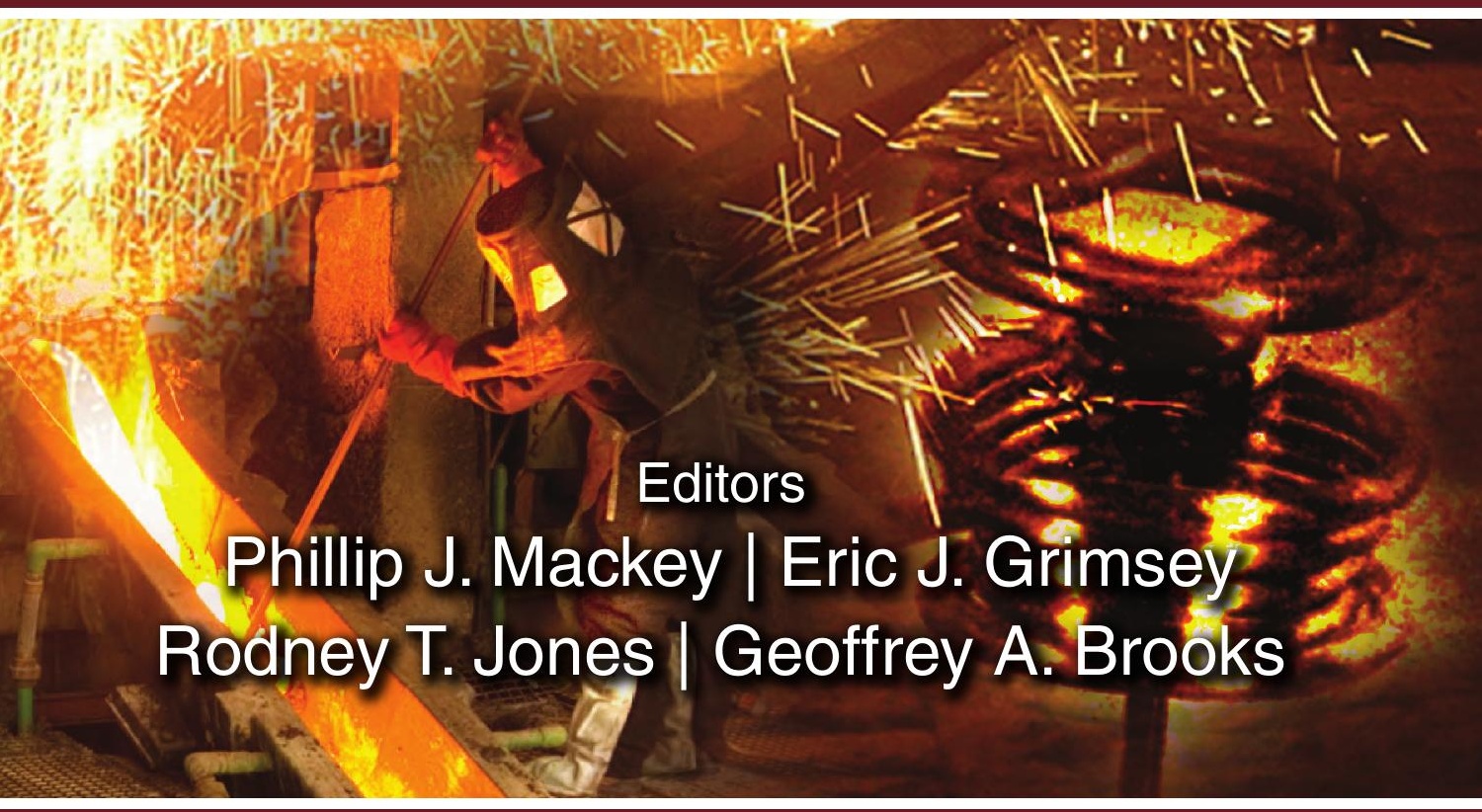

